\section{ASPHALT CONCRETE MIXTURE PRODUCED USING RECLAIMED ASPHALT PAVEMENT AND FLY ASH AS ARTIFICIAL AGGREGATE AND FILLER}

Ari Widayantia,b, Ria Asih Aryani Soemitroa*, Januarti Jaya Ekaputria, Hitapriya Suprayitno ${ }^{a}$

aCivil Engineering Department, Institut Teknologi Sepuluh Nopember, Sukolilo, 60111 , Surabaya, Indonesia ${ }^{b}$ Civil Engineering Department, Universitas Negeri Surabaya, Ketintang, 60231, Surabaya, Indonesia
Article history

Received

11 November 2020

Received in revised form

16 April 2021

Accepted

20 April 2021

Published online

20 June 202

*Corresponding authors ria@ce.its.ac.id

\section{Graphical abstract}

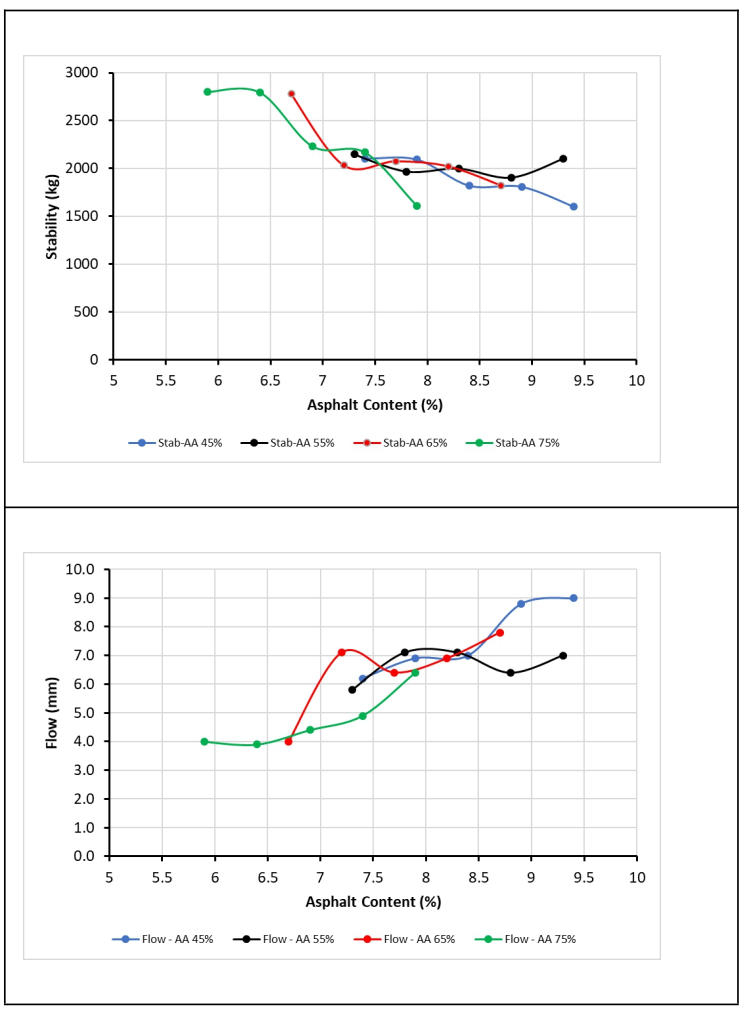

\section{Abstract}

This study presents the use of reclaimed asphalt pavement (RAP), and fly ash as artificial aggregate and filler in asphalt concrete. Because of the limited availability of natural materials, infrastructure development has become a concern. Therefore, it is necessary to reuse and recycle the waste materials. One such innovation is artificial aggregates. The disadvantage of RAP is that its gradation exceeds the standard; its asphalt penetration and ductility exceed the requirements. The weaknesses of artificial aggregate are high water absorption, spherical shape, and low aggregate interlocking. In this study, the artificial aggregate was produced using the fly ash and alkali activator. Alkali activator consisted of $\mathrm{Na}_{2} \mathrm{SiO}_{3}$ and $8 \mathrm{M} \mathrm{NaOH}$ at a ratio of 2.5. The mixtures containing different percentages of artificial aggregate $(45,55$, 65 , and $75 \%$ ) were produced, and the fly ash filler content was $5 \%$. Different tests including XRF, SEM, and Marshall tests were conducted. The artificial aggregate is hydrophilic owing to the high silica content; thus, it has high water absorption. This results in a low adhesion between the asphalt and aggregate. The best composition of asphalt concrete is $55 \%$ artificial aggregate, RAP, fly ash filler, and asphalt. The asphalt concrete containing artificial aggregate has a high stability and is stiff and light. However, it requires a high asphalt content because of a high-water absorption. It is unsuitable for application in high traffic roads, but suitable for medium traffic ones.

Keywords: Asphalt concrete, RAP, fly ash, artificial aggregate, filler (c) 2021 Penerbit UTM Press. All rights reserved 


\subsection{INTRODUCTION}

Infrastructure development is a priority for the Indonesian government. Because of the increasingly limited supply of natural materials, efforts should be made to utilize the waste materials to enhance sustainable construction and environment.

Reclaimed asphalt pavement (RAP) is a material obtained from the dredging of the road pavement layer using a cold milling machine. This RAP contains asphalt and aggregate, which can be recycled and reused. It has been reported that the RAP production capacity of road dredging works in the East Java province is approximately 50,000 $\mathrm{m}^{3}$ /year [1].

The utilization of RAP offers economic benefits and preserves natural resources [2]. The usage of high content of RAP can decrease the energy required to produce the asphalt concrete and conserve the aggregates and asphalt resources [3]. Therefore, RAP could be one of the best approaches to enhance sustainable construction. All the pavements reach the end of service life at a certain point and require to be recycled [4]. Currently, the use of waste materials to decrease the construction cost and increase the strength of materials has not been investigated extensively [5]. However, the usage of RAP in the East Java province is in the range of $20-30 \%$ [6]. The economic benefit of the utilization of RAP is that is cost efficient, and it preserves natural aggregates and asphalt [7].

However, RAP offers certain disadvantages such as the lack of gradation, ductility, and penetration of RAP. These are not in accordance with the specifications [1]. The mixture incorporated with RAP induces brittleness in asphalt concrete [8]. Therefore, to utilize RAP, it is required to investigate the microstructure of mixture [9].

The RAP has an extremely limited bonding because the particles are coated with aged asphalt. This bonding can be improved by incorporating natural aggregates and/or calcium-based additives such as lime, cement, or fly ash into RAP [10]. Based on the damage analysis, the base layer thickness of a cement-treated base reduces by $50 \%$ when $80 \%$ RAP: $20 \%$ aggregate mixture stabilized with $40 \%$ fly ash is used as compared to original conventional aggregates [11].

The difference between this study and the others is the material composition. In this study, RAP, fly ash, and asphalt were used; fly ash was used as the artificial aggregate and filler. In other studies, different combinations of materials were used: RAP and natural aggregate [9]; RAP, crumb rubber, and granite aggregate [12]; RAP, rejuvenator, and natural aggregate [13]; RAP and crumb rubber [14]; RAP and reclaimed asphalt shingles [15]; RAP and natural aggregate [16]; RAP, crumb rubber, and granite [17]; RAP and natural aggregate [18]; only RAP [19]; RAP, hot mix asphalt, and warm mix asphalt
[20]; only RAP [21]; RAP in hot mix asphalt [22]; warm mix asphalt with high RAP [23]; and RAP and warm mix recycled asphalt [24].

Further, the power plant industry produces coal ash as a waste product. This coal ash consists of fly ash and bottom ash. The coal ash production of the Suralaya Power Plant increased to approximately 2.7 million tons/year, and it is predicted to increase up to approximately 11.2 million tons/year [25]. This substantial rise in production will require a large storage space and cause environmental problems. Therefore, to alleviate these issues, the fly ash can be utilized to produce artificial aggregate and filler. This is one strategy to support the infrastructure development. In Indonesia, the utilization of fly ash is control restricted because it is hazardous. However, the solidification of fly ash decreases the hazardous effects of fly ash [26].

In this study, the disadvantage of RAP gradation has been reduced by the artificial aggregate addition. However, the use of fly ash as an artificial aggregate and filler is limited to concrete [27]-[38].

In addition, the differences between this study and the others are the raw material, manufacturing process, and resultant products of artificial aggregate. The raw material of artificial aggregate consisted of fly ash, bottom ash, recycled aggregate, marble, granite, marine sediment, etc. The manufacturing process of artificial aggregate mostly involved a pan granulator and stone crusher machine. This method produced aggregates with a spherical shape, smooth texture, high water absorption, low interlocking between them [31]. It is quite necessary to conduct chemical tests and synthesis studies to characterize the properties of macro- and micro-structure [39]. The morphological properties of aggregate have a great impact on the performance of asphalt concrete [40].

Based on a previous study, the filler used in asphalt concrete consisted of stone dust, fly ash, bottom ash, and solidified coal waste. It was reported that the solidification of coal waste with $8 \mathrm{M}$ $\mathrm{NaOH}$ offered the highest stability [41]. The fly ash is generally classified as F or C class. Furthermore, the fly ash may provide a considerable economy of asphalt. In addition, it provides better strength with lower deformation compared with the conventional mix. Thus, the use of fly ash as the filler can support the global sustainability [1], [42]. The use of $5 \%$ fly ash as the filler, 20\% RAP, natural aggregate, and asphalt can achieve an optimal performance according to the specifications except for VIM in PRD/Voids in Mix in Percentage Refusal Density [1].

The novelty of this study is the use of RAP and fly ash as the artificial aggregate and filler in asphalt concrete. The objective of this study is to evaluate the performance of asphalt concrete containing RAP, and fly ash as the artificial aggregate and filler. 


\subsection{METHODOLOGY}

Research Materials

The materials consisted of RAP, asphalt, and fly ash as the artificial aggregate and filler. The RAP was obtained from the national road of Taman-Waru, Sidoarjo, East Java, Indonesia. The asphalt pen 60/70 was used. The fly ash was obtained from the Suralaya Power Plant Unit 1-7, Cilegon, Banten, Indonesia. This fly ash was classified as $\mathrm{F}$ class [43]. The artificial aggregate was produced from fly ash $(75 \%)$ and alkali activator (25\%). A total of $75 \%$ of fly ash was used to utilize it as much as possible, and it was mixed homogeneously. The alkali activator ratio $\left(\mathrm{Na}_{2} \mathrm{SiO}_{3} / 8 \mathrm{M} \mathrm{NaOH}\right)$ was 2.5 [43]. The $8 \mathrm{M} \mathrm{NaOH}$ offered the highest strength; this is in line with the previous studies [43], [44]. The artificial aggregate mixture was then casted into a mold, and it was crushed using a stone crusher machine after 28 days.

\section{Research Procedures}

Initially, the RAP was collected randomly from the quarry. Next, the RAP was subjected to an extraction test to obtain the asphalt content of RAP. Subsequently, a gradation analysis was performed to obtain the RAP grading curve. Particularly, this analysis was performed to obtain the combined aggregate gradation and mixture composition. Based on the combined aggregate and asphalt content of RAP, the design of asphalt content was calculated to produce the specimens.

When the artificial aggregate was crushed only once, it was extremely flat. Therefore, it had to be crushed again to obtain a cubical shape and rough surface. For the material properties test, the Indonesian Standard (IS) was referred [45].

The specimens consisting of four compositions with five different plan asphalt contents were produced. The mixtures were then casted into the cylindrical molds. Subsequently, the specimens were compacted 75 times per-field and stored at $20-25^{\circ} \mathrm{C}$ for at least $2 \mathrm{~h}$. The specimens were then immersed in water for $30 \mathrm{~min}$ at a temperature of $60^{\circ} \mathrm{C}$, and they were tested using an engine to obtain their stability and flow. This analysis was performed to obtain the Marshall parameters (stability and flow).

\subsection{RESULTS AND DISCUSSION}

RAP

Based on the extraction test, the asphalt content of RAP was determined as $4.37 \%$. It indicated that RAP could still be reused for asphalt concrete. Figure 1 displays the RAP material.

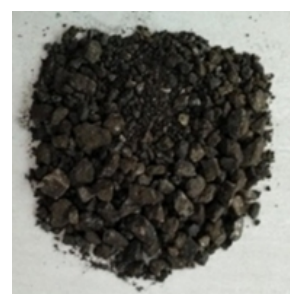

Figure 1 RAP material

The variations in size of RAP were determined using sieving analysis. The results of sieving analysis illustrate the RAP gradation, as shown in Figure 2.

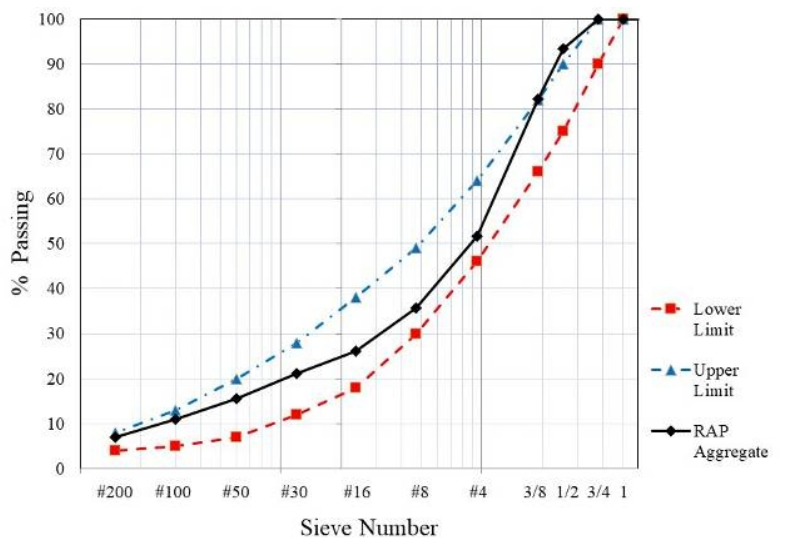

Figure 2 RAP gradation curve of AC-BC mixture

Figure 2 displays the RAP gradation of $A C-B C$ mixture. In this curve, the sizes of $3 / 8$ " and $1 / 2$ " exceeds from standard. This is because the RAP aggregates were mixed and the pavement had undergone degradation and disintegration due to the repeated loading of vehicles, weather, climate, rainfall, and chemical reactions. Therefore, to achieve the gradation that meets the requirements, the addition of aggregates is necessary. In this regard, previous studies employed natural aggregates [9], [13], [16], [18]; however, in this study, artificial aggregate has been employed.

The addition of artificial aggregate can overcome the issues of RAP gradation. The artificial aggregate with a composition of $75 \%$ fly ash and $25 \%$ alkali activator $\left(\mathrm{Na}_{2} \mathrm{SiO}_{3}\right.$ and $8 \mathrm{M} \mathrm{NaOH}$; with a ratio of 2.5) exhibited the highest strength [27], [43], [46] owing to the chemical composition of fly ash comprising the largest Si/Al obtained from the Suralaya unit.

\section{Mix Gradation}

The gradation determines the quality of asphalt concrete, and it is largely composed of aggregate (90-95\% in weight percentages). Gradation is the most important property of an aggregate, and it is a primary consideration in the asphalt concrete design. 
A good aggregate gradation is dense/well graded. It consists of a mixture of coarse and fine aggregates at a balanced percentage. This aggregate offers the maximum density and high stability by increasing the inter-particle contact and reduces VMA/Voids in Mineral Aggregate.

The produced mixtures consisted of four different artificial aggregate compositions: 45, 55, 65, and $75 \%$. The filler percentage of $5 \%$ was obtained from the previous study, where the same RAP source was used; which results in mixed aggregate gradation meet the standard [1]. The mix aggregate gradations are shown in Figures 3-6.

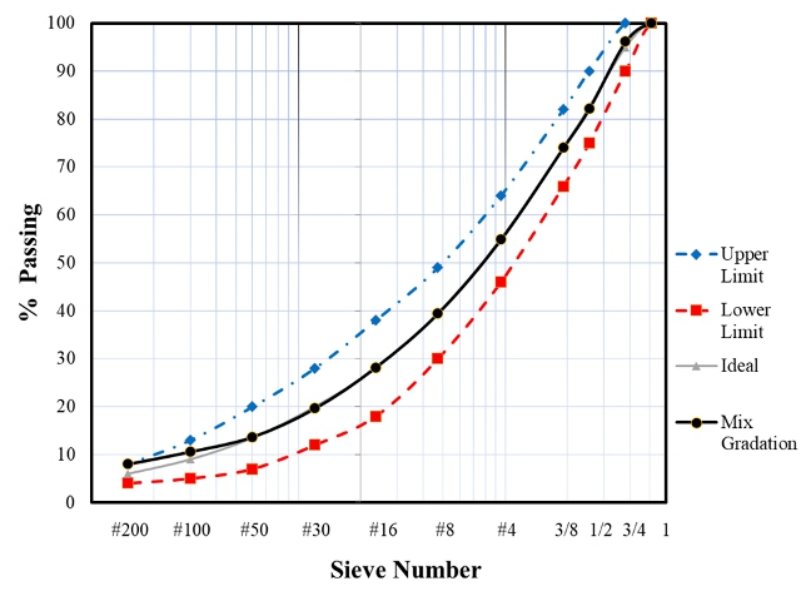

Figure 3 Gradation curve of mixture containing $45 \%$ artificial aggregate

From Figure 3 , it is obvious that the mix aggregate gradation approaches the ideal gradation of asphalt concrete mixture. This is expected to produce the maximum density and high stability.

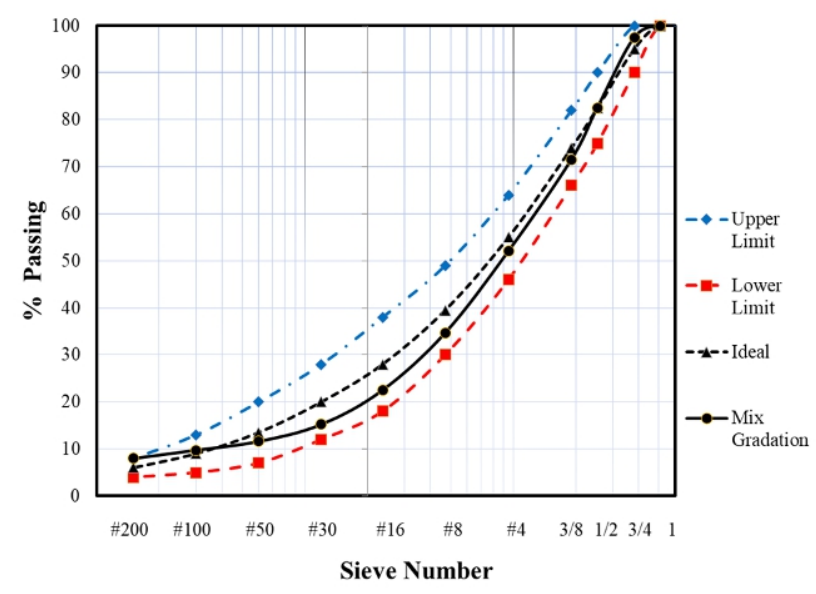

Figure 4 Gradation curve of mixture containing 55\% artificial aggregate

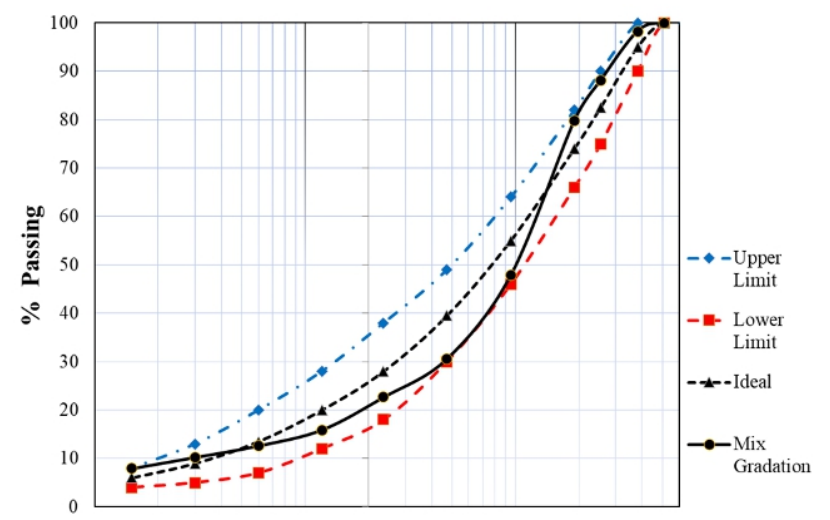

Sieve Number

Figure 5 Gradation curve of mixture containing $65 \%$ artificial aggregate

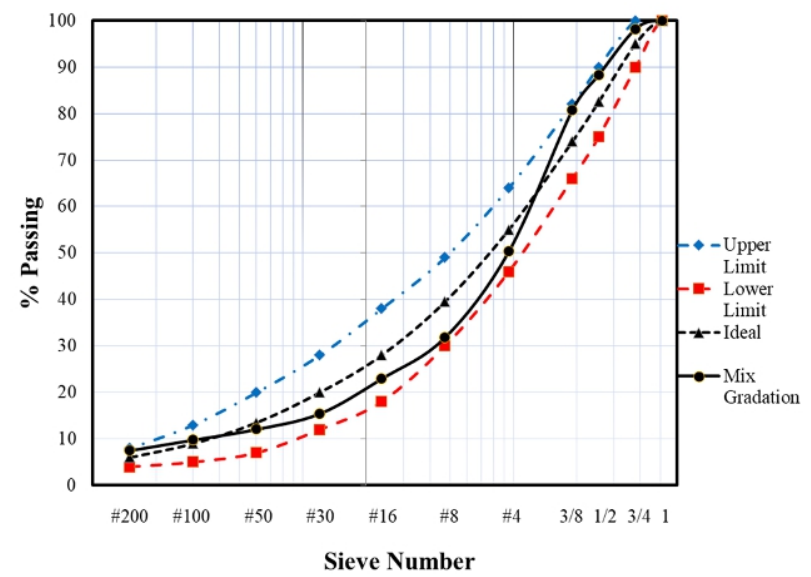

Figure 6 Gradation curve of mixture containing $75 \%$ artificial aggregate

Figures 4-6 indicate that the mix aggregate gradation approaches the lower limit; in other words, this gradation can be classified as a coarse one. This is in line with the dense-graded criteria of asphalt concrete mixture. These mixtures were expected to offer a high stability and water-resistance.

\section{The Aggregate Properties}

The artificial aggregate is depicted in Figure 7.

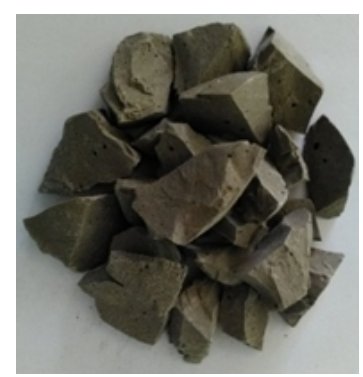

Figure 7 Artificial aggregate 
The properties test results of artificial and RAP aggregates are summarized in Table 1.

Table 1 Properties of artificial and RAP aggregates

\begin{tabular}{|c|c|c|c|c|}
\hline \multirow[t]{2}{*}{ No. } & \multirow[t]{2}{*}{ Parameters } & \multicolumn{2}{|c|}{ Results } & \multirow[t]{2}{*}{ IS } \\
\hline & & Artificial & RAP & \\
\hline 1 & Soundness (\%) & 5.69 & 3.15 & Max. 12 \\
\hline 2 & Abrasion (\%) & 28 & 20.19 & Max. 40 \\
\hline 3 & $\begin{array}{l}\text { Water absorption } \\
\text { (\%) }\end{array}$ & $14.90^{*}$ & 1.42 & Max. 3 \\
\hline 4 & Affinity (\%) & $<95^{*}$ & $>95$ & Min. 95 \\
\hline 5 & Angularity & $100 *$ & $95 / 90$ & $95 / 90$ \\
\hline 6 & $\begin{array}{l}\text { Specific } \\
\left(\mathrm{g} / \mathrm{cm}^{3}\right)\end{array}$ & $2.44^{*}$ & 2.60 & Min. 2.5 \\
\hline 7 & $\begin{array}{l}\text { Flaky and } \\
\text { elongated (\%) }\end{array}$ & 3.17 & 2 & Max. 10 \\
\hline 8 & $\begin{array}{l}\text { Passing through } \\
\text { sieve no. } 200(\%)\end{array}$ & 0.30 & 0.47 & Max. 2 \\
\hline
\end{tabular}

From Table 1, it is obvious that the RAP aggregate meets all the requirements of the standard. Thus, the RAP aggregate can be used in asphalt concrete mixtures.

The artificial aggregate does not meet the standard requirements of the following parameters: water absorption, affinity, angularity, and specific gravity. Therefore, the artificial aggregate should be crushed again to obtain a cubical shape and rough surface. This is performed to improve the interlocking between aggregates and make them more suitable for aggregates of road pavement.

Affinity is the ability of aggregate to bind with asphalt. The affinity of artificial aggregate is less than 95\%. One of the most important effects of aggregate mineralogy on the performance of mixture is its influence on adhesion. Normally, asphalt bonds better with the carbonate aggregates such as limestone than the siliceous aggregates such as gravel. In addition, the aggregate with a low silica content is the best. This aggregate is hydrophobic (water-hating); therefore, it has a higher affinity toward asphalt [47], [48]. In contrast, the aggregates with a high silica content are hydrophilic (waterloving). The nature of electric charges on the aggregate surface significantly affects the adhesion between the aggregate and asphalt when it is in contact with water.

Table 2 X-Ray Fluorescence test result

\begin{tabular}{clrrr}
\hline No. & Compounds & \multicolumn{3}{c}{ Content (weight \%) } \\
& & \multicolumn{1}{c}{ RAP } & \multicolumn{1}{c}{ Artificial } & \multicolumn{1}{c}{ Fly Ash } \\
\hline 1 & $\mathrm{SiO}_{2}$ & 38 & 46.5 & 43.8 \\
2 & $\mathrm{Al}_{2} \mathrm{O}_{3}$ & 11 & 15 & 23 \\
3 & $\mathrm{Fe}_{2} \mathrm{O}_{3}$ & 26.8 & 21.3 & 10.6 \\
4 & $\mathrm{CaO}$ & 16.3 & 10.9 & 10.2 \\
5 & $\mathrm{MgO}$ & - & - & 4.3 \\
6 & $\mathrm{SO}_{3}$ & 2.9 & 1.5 & 1 \\
7 & Others & 5 & 4.8 & 7.1 \\
\hline
\end{tabular}

From Table 2, it shows that the artificial aggregate has a higher silica content than that of RAP. Because the aggregate with a high silica content is hydrophilic, it has a low affinity. In addition, it has a high-water absorption and low/inadequate asphalt bonding. Thus, hydrophilicity is commonly considered an indication of the affinity of aggregate toward water [49].

The results of this study mentioned in the following are similar with those of the other studies. The artificial aggregate has a low specific gravity [26] and high water absorption [26], [31]. The shape and size of artificial aggregate should be considered to produce qualified aggregates [30]. The artificial aggregate exhibited a high compressive strength and high workability [50].

The scanning electron microscope (SEM) images of RAP and artificial aggregates are displayed in Figures 8 and 9.

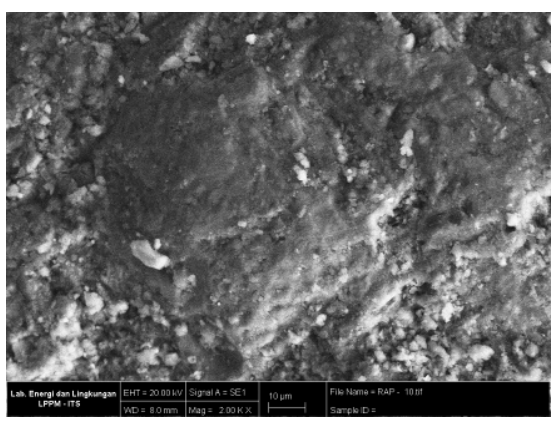

Figure 8 SEM image of RAP aggregate (2000 x)

From Figure 8, it is clear that the RAP aggregate consists of layers and fragments that were formed over a long time due to changes in temperature, climate, and rain. The RAP is partly solid and partly composed of small loose particles and white and black minerals. In addition, the RAP particles have rough surfaces and irregular shapes of varying sizes.

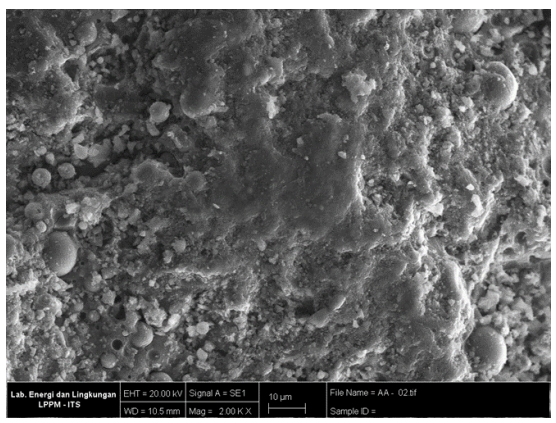

Figure 9 SEM image of artificial aggregate (2000 x)

From Figure 9, it indicates that some part of the artificial aggregate is solid owing to the fly ash and alkali activator; thus, it forms a dense paste matrix. In addition, fine material particles, some of which are 
perfectly spherical and some that are not, can be observed. This indicates that the fly ash did not react properly with the alkaline activator. The abrasion in artificial aggregate was higher when compared to that in RAP aggregate.

\section{The Fly Ash Properties}

The fly ash used as the filler is displayed in Figure 10.

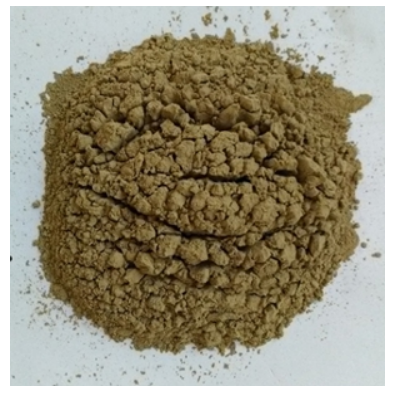

Figure 10 Fly ash (filler)

Figure 10 shows that the color of fly ash is yellowish-light brown. The fly ash contained finegrained material particles of a small size and smooth, spherical, and regular shape [43]. The observation that the fly ash contained particles of spherical shape, different sizes, and relatively smooth outer surface similar with the other studies. Most of the particles were hollow and filled with smaller particles inside them. The size of fly ash ranged between 930 and $25,000 \mathrm{~nm}$ [51]. The properties of fly ash are listed in Table 3.

Table 3 The properties of fly ash (filler)

\begin{tabular}{clc}
\hline No. & \multicolumn{1}{c}{ Parameters } & Results \\
\hline 1 & Passing through sieve no. 200 (\%) & 90.25 \\
2 & Specific gravity $\left(\mathrm{g} / \mathrm{cm}^{3}\right)$ & 2.24 \\
\hline
\end{tabular}

From Table 3, it shows that almost all the fly ash particles passed the sieve no. 200; i.e., by $90 \%$. This fly ash can be used directly as the filler. The specific gravity of fly ash was $2.24 \mathrm{~g} / \mathrm{cm}^{3}$, which is similar to that $\left(2.26 \mathrm{~g} / \mathrm{cm}^{3}\right)$ reported in other studies [44]. The fly ash contains particles of an extremely fine size that fill the small gaps in the mixture, thereby increasing the density, stability, and impermeability. The spherical shape of fly ash particles offers better flowability and workability [29]. In addition, it can reduce the possibility of bleeding, segregation, and cracking.

\section{The Asphalt Properties}

The properties of RAP asphalt and asphalt pen 60/70 are presented in Table 4.
Table 4 The properties of RAP asphalt and asphalt pen 60/70

\begin{tabular}{|c|c|c|c|c|}
\hline \multirow[t]{2}{*}{ No. } & \multirow{2}{*}{ Parameters } & \multicolumn{2}{|c|}{ Results } & \multirow[t]{2}{*}{ IS } \\
\hline & & Asphalt pen & RAP & \\
\hline 1 & $\begin{array}{l}\text { Penetration at } \\
25^{\circ} \mathrm{C}(0.1 \mathrm{~mm})\end{array}$ & 62 & $49 *$ & $60-70$ \\
\hline 2 & $\begin{array}{ll}\text { Viscosity } & \text { at } \\
135^{\circ} \mathrm{C} \text { (cSt) }\end{array}$ & 393 & $2,300 *$ & $\geq 300$ \\
\hline 3 & $\begin{array}{l}\text { Softening point } \\
\left({ }^{\circ} \mathrm{C}\right)\end{array}$ & 49.1 & 55 & $\geq 48$ \\
\hline 4 & $\begin{array}{l}\text { Ductility at } \\
25^{\circ} \mathrm{C}(\mathrm{cm})\end{array}$ & $>140$ & $>120$ & $\geq 100$ \\
\hline 5 & Flash point $\left({ }^{\circ} \mathrm{C}\right)$ & 240 & - & $\geq 232$ \\
\hline 6 & $\begin{array}{l}\text { Solubility of } \\
\text { trichloroethylen } \\
\text { e (\%) }\end{array}$ & 99.82 & 99.85 & $\geq 99$ \\
\hline 7 & $\begin{array}{l}\text { Specific gravity } \\
\left(\mathrm{g} / \mathrm{cm}^{3}\right)\end{array}$ & 1.03 & 1.07 & $\geq 1.0$ \\
\hline \multicolumn{5}{|c|}{$\begin{array}{l}\text { Residue test using thin film oven and rolling thin film oven } \\
\text { tests }\end{array}$} \\
\hline 8 & Weight loss (\%) & 0.21 & - & $\leq 0.8$ \\
\hline 9 & $\begin{array}{l}\text { Penetration at } \\
25^{\circ} \mathrm{C}(0.1 \mathrm{~mm})\end{array}$ & 58 & - & $\geq 54$ \\
\hline 10 & $\begin{array}{l}\text { Ductility at } \\
25^{\circ} \mathrm{C}(\mathrm{cm})\end{array}$ & 100 & - & $\geq 100$ \\
\hline
\end{tabular}

Table 4 indicates that the penetration of RAP asphalt is lower than that of the standard. The penetration indicates the level of asphalt hardness, whereas the viscosity indicates the consistency of asphalt. The low penetration and extremely high viscosity of RAP asphalt indicate that it is hard and brittle. This is because the RAP asphalt has undergone aging, disintegration, and deformation due to repeated traffic loading. In addition, because it has been laid on the road for a long time, the surface of asphalt aggregate undergoes oxidation. The asphalt hardening is likely due to oxidation, evaporation, and chemical changes. Therefore, to improve the RAP asphalt quality, asphalt should be added.

The properties of asphalt pen 60/70 agree with those outlined by the standard; thus, it can be used as the binder in $A C-B C$ mixtures.

\section{Properties of Mixture}

The specimens were applied to asphalt concrete mixture, as shown in Figure 11. 


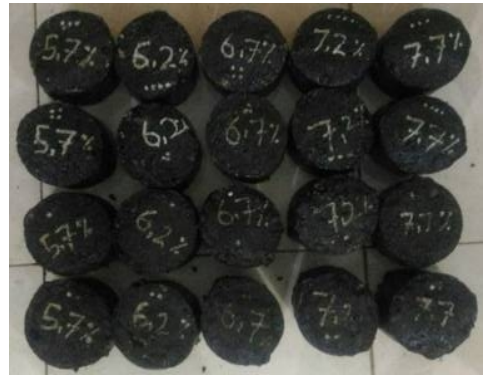

Figure 11 The Specimen of AC-BC

The relationship between the asphalt content and Marshall parameters is shown in Figures 12-18.

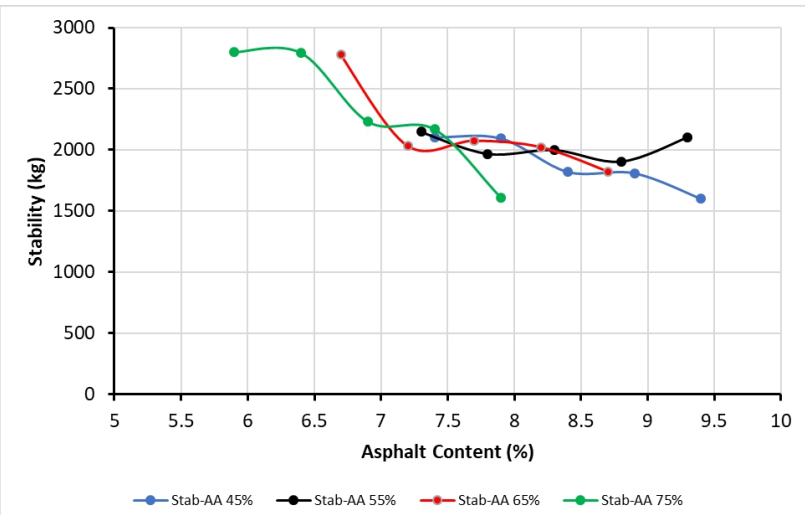

Figure 12 Stability

As shown in Figure 12, the stabilities of all the mixtures are higher than $800 \mathrm{~kg}$, which is the minimum standard for the AC-BC mixture. The highest stability of $2799 \mathrm{~kg}$ was exhibited by the mixture containing 75\% artificial aggregate, whereas the lowest stability of $1600 \mathrm{~kg}$ was exhibited by the mixture containing $45 \%$ artificial aggregate.

The addition of artificial aggregate increases the stability. This is caused by the increase in artificial aggregates, which have the ability to withstand a high compressive strength. It has been reported that the artificial aggregates containing $\mathrm{Na}_{2} \mathrm{SiO}_{3}$ and $8 \mathrm{M}$ $\mathrm{NaOH}$ at a ratio of 2.5 have a high compressive strength [43].

It was observed that the mixture containing $75 \%$ artificial aggregate and low asphalt content exhibited a flow according to the standard, as shown in Figure 13. A high flow indicates that the mixture is plastic, and it undergoes permanent deformation under traffic loading. In contrast, a low flow may indicate large number of voids and insufficient amount of asphalt that is required for durability. This results in premature cracking due to the brittleness of mixture during the life of pavement. Thus, flow is a function of the binding asphalt stiffness and asphalt content of mixture. In addition, it is an indicator of the flexibility of asphalt mixture.

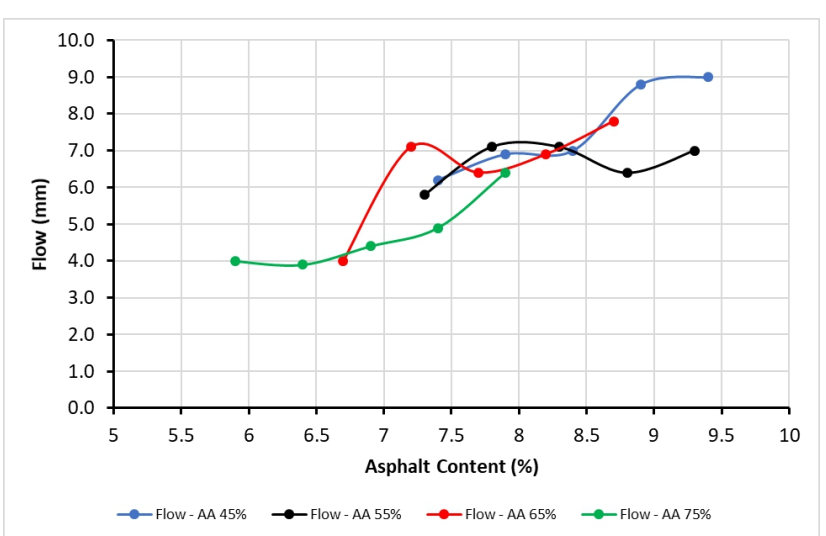

Figure 13 Flow

The flows obtained using the mixture containing $75 \%$ artificial aggregate at asphalt contents of 5.9 and $6.4 \%$ meet the standard, whereas those obtained using the mixtures containing other percentages of artificial aggregates do not meet the requirements. The highest flow was obtained for the mixture containing $45 \%$ artificial aggregate, whereas the lowest flow was obtained for the mixture containing $75 \%$ artificial aggregate.

The addition of artificial aggregate decreases the flow, and the addition of asphalt increases the flow. However, with the increase in asphalt content, the mixture becomes more plastic. Furthermore, a high asphalt content results in a better coverage of the aggregate. This strengthens the bond between aggregate and asphalt.

The artificial aggregate is porous and has a high water absorption (14.9\%). This observation is similar to those of the previous studies, which reported that it is in the range of $0.7-33.9 \%$ [35], [52]. The use of porous aggregates requires more amount of asphalt than that present in the RAP aggregate to cover the artificial aggregate. If lower asphalt contents are used, lower flows will be obtained.

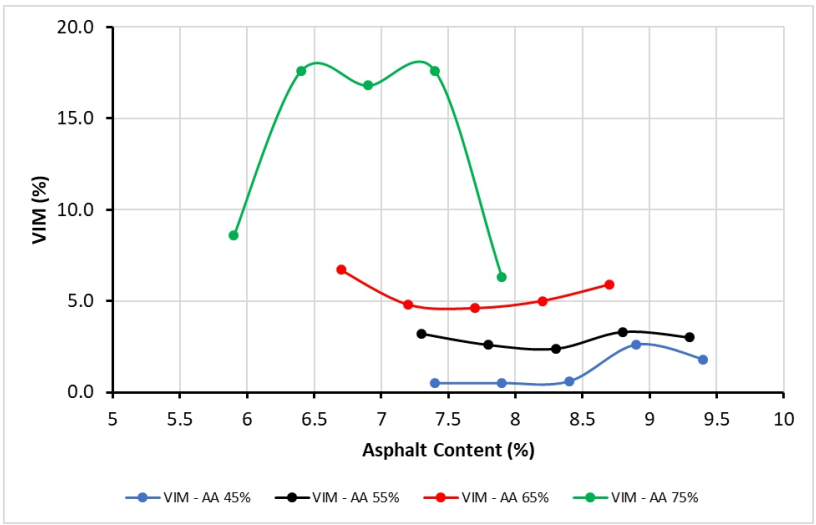

Figure $14 \mathrm{VIM} /$ Voids in Mixture 
Figure 14 shows that the highest VIM is exhibited by the mixture containing $75 \%$ artificial aggregate, whereas the lowest VIM is exhibited by the mixture containing $45 \%$ artificial aggregate. The VIM of the mixtures containing 55 and $65 \%$ artificial aggregates meet the VIM requirements of $3-5 \%$. The addition of artificial aggregate with a low asphalt content increases the VIM. This is evident in the mixture containing $75 \%$ artificial aggregate owing to its morecoarse fraction and low asphalt content. In contrast, the use of dense and almost ideal gradation $(45 \%$ artificial aggregate) decreases the VIM. In other words, increase in asphalt content reduces the VIM. Furthermore, a high VIM decreases the impermeability and increases the asphalt oxidation, which can accelerate the aging of asphalt. In addition, it can reduce the durability. However, a low VIM increases the possibility of bleeding if the temperature rises.

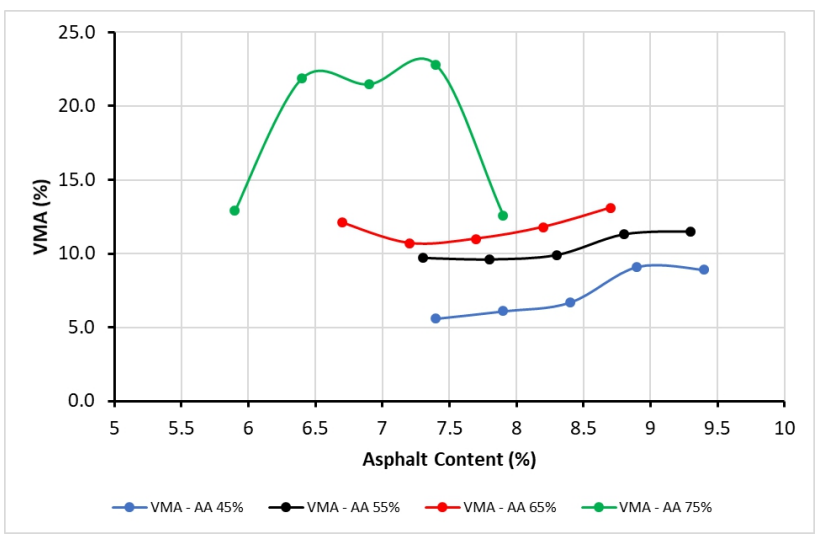

Figure $15 \mathrm{VMA}$ /Voids in Mineral Aggregate

Figure 15 shows that the VMA of the mixture containing $75 \%$ artificial aggregate meets the requirements. The highest VMA is exhibited by the mixture containing $75 \%$ artificial aggregate, whereas the lowest VMA is exhibited by that containing $45 \%$ artificial aggregate. This is due to the more coarsedense gradation of artificial aggregates in the mixture containing $75 \%$ artificial aggregates, whereas the gradation is more-dense in that containing $45 \%$ artificial aggregates.

The addition of artificial aggregate increases the VMA. In addition, the VMA is closely related to density; the higher the density, lower is the VMA. A Iow VMA results in a highly durable mixture, whereas a high VMA induces a large deformation. An increase in asphalt content decreases the VMA to a minimum point, and with the further increase in asphalt content, it increases. This is because the asphalt fills the voids between aggregates to a point where no more voids can be filled. At this point, the VMA is minimum.

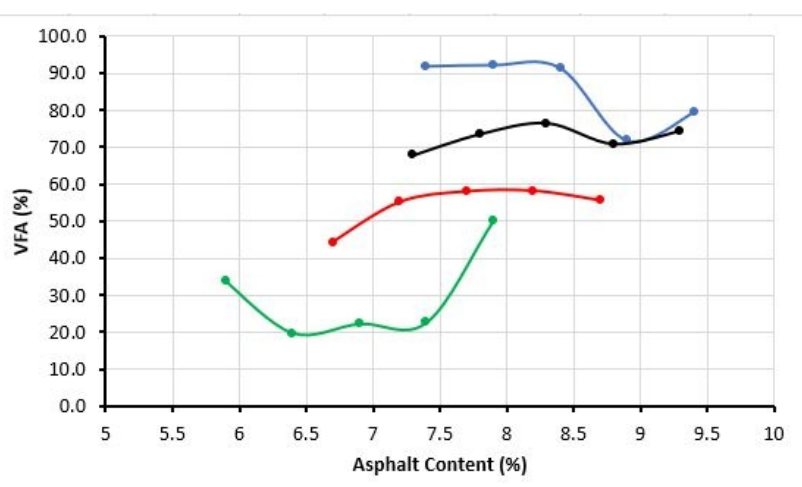

$\rightarrow$ VFA-AA45\% -VFA-AA55\% -VFA-AA65\% -VFA-AA $75 \%$

Figure 16 VFA/Voids Filled with Asphalt

Figure 16 shows that the highest VFA is exhibited by the mixture containing $45 \%$ artificial aggregate, whereas the lowest VFA is exhibited by that containing $75 \%$ artificial aggregate. The VFA of the mixtures containing 45 and $55 \%$ artificial aggregates meet the VFA standard (higher than 65\%). The addition of artificial aggregate decreases the VFA. This is because an increase in the amounts of artificial aggregates, which have a high-water absorption, demands higher asphalt contents; thus, the VFA decreases. When the asphalt content is increased, it is absorbed into the artificial aggregate; thus, the asphalt film becomes thinner. To meet the standard, an asphalt content of at least $7 \%$ should be available in the artificial aggregate of the AC-BC mixture so that the asphalt can be absorbed into the aggregate and can cover the aggregate better.

The mixtures containing 65 and $75 \%$ artificial aggregates exhibited a low VFA; this decreases the impermeability of the mixture toward water because a small number of voids are filled with asphalt. This allows the water and air to enter the pavement layer, thereby reducing the durability of the pavement mixture. A high VFA indicates that large number of voids are filled with asphalt, and the pavement layer is more impermeable to water and air; therefore, the elasticity is high. However, this can result in pavement bleeding.

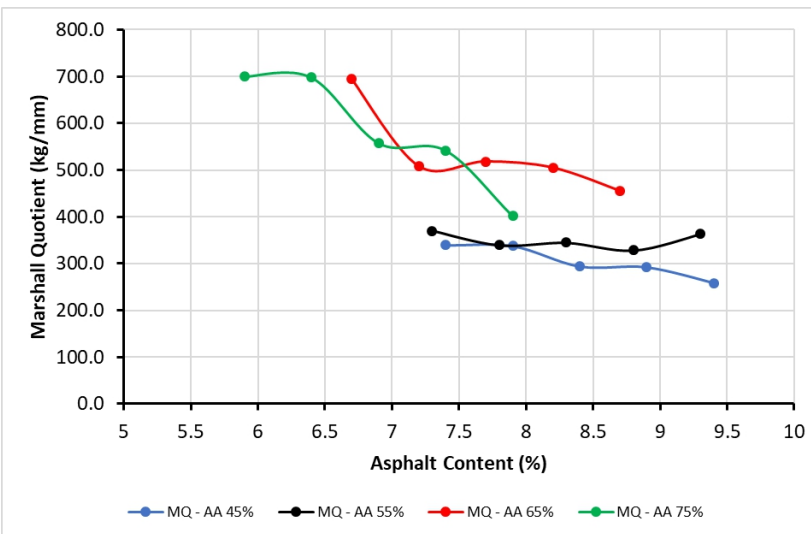

Figure 17 Marshall quotient 
Figure 17 shows that the highest Marshall quotient is exhibited by the mixture containing $75 \%$ artificial aggregate, whereas the lowest Marshall quotient is exhibited by the mixture containing $45 \%$ artificial aggregates. Marshall quotient is a potential indicator of the flexibility of cracks. A high Marshall quotient indicates that the mixture is more rigid; on the contrary, a low value indicates that the mixture is more flexible. The flexible pavement tends to be flexible and deform if the pavement receives a traffic load. In contrast, a rigid pavement crack easily.

All the mixtures used in this study exhibit flexibility in the range according to the standard. However, a high Marshall quotient, implying a rigid mixture, is obtained for the mixtures containing 65 and $75 \%$ artificial aggregates at a low asphalt content of $7 \%$. This is likely due to the extremely high stability obtained by the addition of artificial aggregate and a low flow caused by the low asphalt content.

The addition of artificial aggregate increases the Marshall quotient. This is due to the increase in amount of artificial aggregate, which has the ability to withstand high loads, and because of the insufficient asphalt content, the mixture tends to crack easily. Therefore, to obtain a strong and flexible mixture, a strong aggregate with a gap gradation and therefore a large VMA is required. In addition, a soft asphalt that has high penetration and sufficient asphalt content is required to obtain a low VIM.

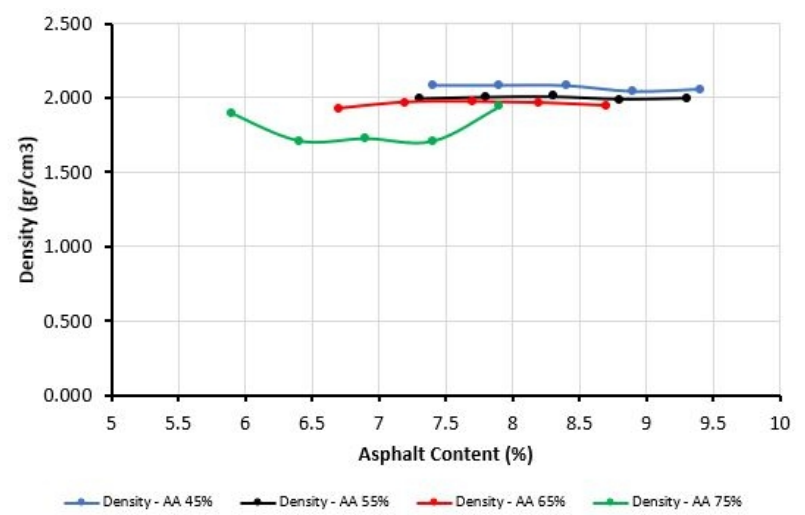

Figure 18 Density

Figure 18 illustrates that the highest density is exhibited by the mixture containing $45 \%$ artificial aggregate, whereas the lowest density is exhibited by that containing $75 \%$ artificial aggregate. In all the four mixtures, the density increased with the addition of asphalt and RAP. However, the addition of artificial aggregate decreases the density because the specific gravity of artificial aggregate $(2.44$ $\mathrm{g} / \mathrm{cm}^{3}$ ) is lower than that of RAP aggregate (2.6 $\left.\mathrm{g} / \mathrm{cm}^{3}\right)$. Generally, the specific gravity of artificial aggregate is in the range of $1.33-2.35 \mathrm{~g} / \mathrm{cm}^{3}$ [35], [52].

The use of dense-ideal gradation of artificial aggregate $(45 \%)$ causes the mixture to have a high density. With the addition of artificial aggregate, the density of mixture decreases. Therefore, it is suggested that artificial aggregates are one of the potential candidates for lightweight asphalt concrete.

The artificial aggregate offers a high-water absorption and low specific gravity. The use of fly ash increases the performance of construction material [26]. In addition, it has been reported that the geopolymer offered a high mechanical strength and better bonding owing to the surface roughness of the aggregate [28].

Thus, the artificial aggregate improves the physical and mechanical properties of the construction material [35], [53]-[56], offers better thermal properties [57], offers a high compressive strength and workability [52], and improves the workability [56], [58] and flowability [58].

Furthermore, the artificial aggregate offers a high crack and moisture resistance, volume stability, and deformation resistance to the asphalt mixture [56]. Moreover, it has been reported that the asphalt film aging had a positive effect on the bonding in dry conditions [59]. In addition, the addition of a geopolymer into the mixtures increased the hardness of asphalt binders. This contributed to the reduction of dumping areas used to dispose fly ash; this, in turn, helps to protect the environment [44].

\section{Discussion}

The gradation determines the quality of asphalt concrete mixtures, and the ideal gradation is determined as dense- or well-graded because this gradation can offer a high stability and density and results in a small number of voids in the mixture, thereby increasing the strength of the mixture.

From the results of RAP gradation, it was observed that the RAP does not meet the requirements of asphalt concrete [45]. Therefore, to meet the requirements, aggregates should be added. In this regard, previous studies used natural aggregates [9], [13], [16], [18], whereas in this study, artificial aggregates were used.

According to previous studies, the artificial aggregates exhibit a spherical shape (pelletizer), smooth surface, high water absorption [35], [52], low aggregate interlocking, and low asphalt adhesion. This, however, was unsuitable for road pavement. In this study, the artificial aggregates exhibited a cubical shape (using a crusher stone machine), rough surface, and high aggregate interlocking; thus, it is suitable for road pavement.

The cubical artificial aggregate has a highwater absorption (14.9\%), low aggregate adhesion, low specific gravity, high angularity, and high abrasion (these exceed the requirements). In addition, it is porous. According to previous studies, the water absorption was in the range of $0.7-33.9 \%$ [52].

The artificial aggregate exhibits a low adhesion because the aggregate is produced using fly ash 
that has a high silica content. A high silica content causes the aggregate to easily absorb water (hydrophilic or water-loving); therefore, the water absorption is high and the adhesion is low. A hydrophobic material is preferred to obtain a good adhesion between the asphalt and aggregate [47] [48].

Furthermore, the artificial aggregate has a low specific gravity $\left(2.44 \mathrm{~g} / \mathrm{cm}^{3}\right)$ because it is produced using fly ash that has a low specific gravity. This observation similar with the other studies, where the specific gravity of artificial aggregate produced using fly ash is in the range of $1.33-2.35 \mathrm{~g} / \mathrm{cm}^{3}$ [52].

Moreover, the artificial aggregate has a high angularity. This helps in producing aggregates with rough and angled surfaces, thereby resulting in a high aggregate interlocking.

In addition, the artificial aggregate exhibits high abrasion because it is produced using fly ash that is in the form of granules and is reacted with an alkaline activator. The SEM image of fly ash indicates that not all the fly ash is reactive; thus, it does not form a geopolymer paste. Further, if the artificial aggregates are loaded repetitively, it produces a high abrasion (below the maximum limit). However, if they are subjected to a load only once, they will have a high compressive strength and therefore a high stability [43].

The fly ash contains a high silica content; therefore, it produces a hard and strong material. The fly ash contains particles that have a spherical shape and fine size, and are hygroscopic. Spherical particles offer a high flowability; thus, they can flow easily. Fine particles fill the voids in the mixture and offer a high mixture density, small number of voids, high stability, strength, and durability to the material.

The asphalt pen 60/70 was included in the standard specification for comparison. These specifications are similar to those of the previous study [1].

RAP asphalt undergoes oxidation and therefore has a high viscosity, resulting in the hardening of asphalt. In addition, the chemical composition of asphalt changes; resins convert to asphaltenes and oils convert to resins. RAP asphalt has a low penetration and high viscosity. This observation agrees with the previous studies [9], [13], [16], [18]. Further, the RAP asphalt is hard and brittle because the pavement has undergone aging and experienced changes due to repeated loads, chemical changes, climate, rainwater, and temperature.

However, the best composition of AC-BC mixture is observed as $55 \%$ artificial aggregate, RAP, fly ash filler, and asphalt. The dense-graded gradation tends to be below the curve. Thus, it can offer a high stability and density. The voids can still be filled with asphalt by the repeated loading of vehicles.

Pores present in the mixture allow the asphalt to flow and fill the voids in the mixture. When much number of voids is filled with asphalt, the durability increases.

The stabilities of the mixtures were higher than the minimum requirements. This is attributed to the high content of artificial aggregate, which has the ability to withstand high loads. In addition, the flows exhibited by the mixtures were higher than the requirements; the higher the asphalt content, the thicker is the asphalt film.

The Marshall quotient indicates the flexibility of the material. Further, the density of the mixtures was high because the percentage of RAP, which has a higher specific gravity as compared to that of artificial aggregate, was high. According to the Marshall parameter, it is observed that the AC-BC mixture consisting of RAP, fly ash as the artificial aggregate and filler, and asphalt is unsuitable for the high-volume traffic, but suitable for the mediumvolume traffic.

\subsection{CONCLUSION}

Based on the results and discussion, it can be concluded that the lack in gradation of the RAP aggregate can be resolved by the addition of artificial aggregate. This combined aggregate then meets the specification standard.

The artificial aggregate produced using fly ash is hydrophilic and therefore has a high-water absorption. This results in a low adhesion between the asphalt and aggregate. The addition of artificial aggregates affects the requirement of asphalt content in mixtures. Therefore, a high asphalt content is required because the artificial aggregate has a high-water absorption.

The fly ash contains a high silica content; therefore, it can produce a hard and strong material. In addition, the fly ash contains particles that have a spherical shape and fine size, and are hygroscopic. Spherical particles offer a high flowability; thus, they can flow easily. Fine particles fill the voids in the mixture and offer a high density, small number of voids in the mixture, high stability, strength, and durability to the material.

The asphalt pen 60/70 was included in the standard for comparison. Thus, it was observed that the RAP asphalt has a low penetration and high viscosity. The RAP asphalt undergoes oxidation and therefore has a high viscosity, resulting in the hardening of asphalt. In addition, it is hard and brittle because the pavement has undergone aging and experienced changes due to repeated loads, chemical changes, climate, water, and temperature.

However, the best composition of AC-BC mixture is observed as $55 \%$ artificial aggregate, RAP, fly ash filler, and asphalt. The AC-BC mixture containing fly ash as the artificial aggregate and filler is stiff, light, and highly stable. However, it is unsuitable 
for application in high traffic, but it may be suitable for medium traffic.

The use of fly ash as the artificial aggregate and filler and RAP contribute to the preservation of natural aggregates, but not asphalt. This is because the $\mathrm{AC}-\mathrm{BC}$ mixture with artificial aggregate requires more asphalt because of a high-water absorption of artificial aggregates.

\section{Acknowledgment}

The authors gratefully acknowledge the generous financial support of LPDP (Lembaga Pengelola Dana Pendidikan)-Ministry of Finance, Ministry of Education and Culture of Republic Indonesia, Rector of Universitas Negeri Surabaya, and Rector of Institut Teknologi Sepuluh Nopember Surabaya.

\section{References}

[1] Handayani, R., Soemitro, R. A. A., Budianto, H., and Ekaputri, J. J. 2016. The Usage of Fly Ash for Reclaimed Asphalt Pavement (RAP), Asphalt Concrete Binder Course (AC-BC) Filler. The 2nd ISST (International Seminar on Science).

[2] Kamaruddin, N. H. M., Hainin, M. R., Hassan, N. A., Abdullah, M. E., and Yaacob, H. 2014. Evaluation of Pavement Mixture Incorporating Waste Oil. Jurnal Teknologi. 71 (3): 93-98.

DOl: http://dx.doi.org/10.11113/jt.v71.3766.

[3] Arshad, A. K., Kridan, F. A. M., Kamaluddin, N. A., and Shafie, E. 2015. Evaluation of Warm Mix Asphalt Performance with High RAP Content. Jurnal Teknologi. 73(4): 51-54.

DOI: http://dx.doi.org/10.11113/jt.v73.4287.

[4] Idham, M. K. and Hainin, M. R. 2015. The Effect of Incorporating Reclaimed Asphalt Pavement on the Performance of Hot Mix Asphalt Mixtures. Jurnal Teknologi. 77(32): 117-123. 2015.

DOI: http://dx.doi.org/10.11113/jt.v77.6992.

[5] Ting, T. L., Jaya, R. P., Hassan, N. A., Yaacob, H., Jayanti, D. S., and Ariffin, M. A. M. 2016. A Review of Chemical and Physical Properties of Coconut Shell in Asphalt Mixture. Jurnal Teknologi. 78(4): 85-89.

DOI: http://dx.doi.org/10.11113/jt.v78.8002.

[6] Widayanti, A., Soemitro, R. A. A., Ekaputri, J. J., and Suprayitno, H. 2018. Performances of Asphalt Concrete Contain Reclaimed Asphalt Pavement from National Road in East Java Province. Jurnal Manajemen Aset Infrastruktur \& Fasilitas. 2(1): 35-43.

DOl: http://dx.doi.org/10.12962/j26151847v2i1.3766.

[7] Widayanti, A., Soemitro, R.A.A., Ekaputri, J. J., and Suprayitno, H. 2019. Gradation Analysis of Reclaimed Asphalt Pavement from National Road as Asphalt Concrete Layer. Journal of Infrastructure \& Facility Asset Management. 1(1): 41-49.

DOI: http://dx.doi.org/10.12962/jifam.vli1.5205.

[8] Parveez, K., Prateek, M. C., Srikanta, T. K., Yathiraj, N., Konnur, S., and Dinesh, S. V. 2014. Study on the Effect of Reclaimed Asphalt Pavement (RAP) on the Mechanical Behaviour of Hot Mix Asphalt (HMA). Proceeding of International Conference on 11 th Transportation Planning and Implementation Methodologies for Developing Countries (11th TPMDC). Transportation Systems Engineering, Dept. of Civil Engineering. IIT Bombay, Mumbai on 10th-12th December 2014. Paper ID: 95.

[9] Sunil, S., Mallesh, K. M., and Candrasekaraiah, T. 2014. Experimental Investigations on the Performance of
Bituminous Mixes with Reclaimed Asphalt Pavement (RAP) Materials (Case Study Tumkur to Chitradurga-NH4). International Journal of Research in Engineering and Technology (IJRET). 3(6): 297-303. DOI: http://dx.doi.org/10.15623/ijret.2014.03.18045.

[10] Saride, S., Avirneni, D., Candra, S., and Javvadi, P. 2015. Evaluation of Fly ash Treated Reclaimed Asphalt Pavement for Base/Subbase Applications. Indian Geotechnical Journal. 45(4): 401-411. DOI: http://dx.doi.org/10.1007/s40098-014-0137-z.

[11] Saride, S. and Avirneni, D. 2017. Strength Characteristics of Geopolymer Fly Ash-Stabilized Reclaimed Asphalt Pavement Base Courses. Geoenvironmental Practicesand Sustainability. 267-275.

DOI: http://dx.doi.org//10.1007/978-981-10-4077-1_27.

[12] Xiao, F., Amirkhanian, S., and Juang, C. H. 2007. Rutting Resistance of Rubberized Asphalt Concrete Pavements Containing Reclaimed Asphalt Pavement Mixtures. Journal of Materials in Civil Engineering. 19: 475-483. DOI: 10.1061/(ASCE)0899-1561 (2007) 19:6(475).

[13] Shen, J., Amirkhanian, S., and Miller, J. A. 2007. Effects of Rejuvenating Agents on Superpave Mixtures Containing Reclaimed Asphalt Pavement. Journal of Materials in Civil Engineering. 376-384. DOI: 10.1061/(ASCE)0899-1561 (2007) 19:5(376).

[14] Xiao, F., Amirkhanian, S. N., Shen, J., and Putman, B. 2009. Influences of Crumb Rubber Size and Type on Reclaimed Asphalt Pavement (RAP) Mixtures. Construction and Building Materials. 23: 1028-1034.

DOI: http://dx.doi.org/10.1016/j.conbuildmat.2008.05.002.

[15] Falchetto, A. C., Montepara, A., Tebaldi, G., and Marasteanu, M. O. 2012. Microstructural and Rheological Investigation of Asphalt Mixtures Containing Recycled Asphalt Materials. Construction and Building Materials. 35: 321-329.

DOI: http://dx.doi.org/10.1016/j.conbuildmat.2012.04.016.

[16] Colbert, B. and You, Z. 2012. The Determination of Mechanical Performance of Laboratory Produced Hot Mix Asphalt Mixtures Using Controlled RAP and Virgin Aggregate Size Fractions. Construction and Building Materials. 26: 655-662.

DOI: http://dx.doi.org/10.1016/j.conbuildmat.201 1.06.068.

[17] Xiao, F., Amirkhanian, S. N., Putman, B. J., and Juang, H. 2012. Feasibility of Superpave Gyratory Compaction of Rubberized Asphalt Concrete Mixtures Containing Reclaimed Asphalt Pavement. Construction and Building Materials. 27: 432-438. DOI: http://dx.doi.org/10.1016/j.conbuildmat.2011.07.024.

[18] Isola, M., Betti, G., Marradi, A., and Tebaldi, G. 2013. Evaluation of Cement Treated Mixtures with High Percentage of Reclaimed Asphalt Pavement. Construction and Building Materials. 48: 238-247.

DOI: http://dx.doi.org/10.1016/j.conbuildmat.2013.06.042.

[19] Bowers, B. F., Huang, B., Shu, X., and Miller, B. C. 2014. Investigation of Reclaimed Asphalt Pavement Blending Efficiency through GPC and FTIR. Construction and Building Materials. 50: 517-523. DOI: http://dx.doi.org/10.1016/j.conbuildmat.2013.10.003.

[20] Xiao, F., Putman, B., and Amirkhanian, S. 2015. Rheological Characteristics Investigation of High Percentage RAP Binders with WMA Technology at Various Aging States. Construction and Building Materials. 98: 315-324. DOI: http://dx.doi.org/10.1016/j.conbuildmat.2015.08.114.

[21] de Lira, R. R., Cortes, D. D., and Pasten, C. 2015. Reclaimed Asphalt Binder Aging and Its Implications in The Management of RAP Stockpiles. Construction and Building Materials. 101: 611-616.

DOI: http://dx.doi.org/10.1016/j.conbuildmat.2015.10.125.

[22] Ma, T., Wang, H., Huang, X., Wang, Z., and Xiao, F. 2015. Laboratory Performance Characteristics of High Modulus Asphalt Mixture with High-content RAP. Construction and Building Materials. 101: 975-982.

DOI: http://dx.doi.org/10.1016/j.conbuildmat.2015.10.160. 
[23] LU, D. X. and Saleh, M. 2016. Laboratory Evaluation of Warm Mix Asphalt Incorporating High RAP Proportion by Using Evotherm and Sylvaroad Additives. Construction and Building Materials. 114: 580-587.

DOI: http://dx.doi.org/10.1016/j.conbuildmat.2016.03.200.

[24] Almeida, M. D., Gomes, J. C., Sangiorgi, C., Zoorob, S. E., and Afonso, M. L. 2016. Performance of Warm Mix Recycled Asphalt Containing up to $100 \%$ RAP. Construction and Building Materials. 112: 1-6. DOI: http://dx.doi.org/10.1016/j.conbuildmat.2016.02.108.

[25] Thahir, Z. A. 2017. Pemanfaatan Fly Ash dan Bottom Ash dari PLTU Suralaya Banten untuk Pembuatan GEOPAV. Institut Teknologi Sepuluh Nopember, Surabaya, Indonesia.

[26] Atmaca, N., Abbas, M. L., and Atmaca, A. 2017. Effects of Nano-silica on The Gas Permeability, Durability and Mechanical Properties of High-strength Lightweight Concrete. Construction and Building Materials. 147: 17-26. DOI: http://dx.doi.org/10.1016/j.conbuildmat.2017.04.156.

[27] Tang, P., Florea, M. V. A., and Brouwers, H. J. H. 2017. Employing Cold Bonded Pelletization to Produce Lightweight Aggregates from Incineration Fine Bottom Ash. Journal of Cleaner Production. 165: 1371-1384. DOI: http://dx.doi.org/10.1016/j.jclepro.2017.07.234.

[28] Yliniemi, Paiva, Ferreira, Tiainen, and Illikainen. 2017. Development and Incorporation of Lightweight Wastebased Geopolymer Aggregates in Mortar and Concrete. Construction and Building Materials. 131: 784-792. DOI: http://dx.doi.org/10.1016/j.conbuildmat.2016.11.017.

[29] Tekin, I., Yasin, M., Gencel, O. I, Bilir, T., Brostow, W., and Hagg, H. E. 2017. Concretes with Synthetic Aggregates for Sustainability. Construction and Building Materials. 133: 425-432.

DOI: http://dx.doi.org/10.1016/j.conbuildmat.2016.12.110.

[30] Nadesan, M. S., and Dinakar, P. 2017. Structural Concrete Using Sintered Fly Ash Lightweight Aggregate: A Review. Construction and Building Materials. 154: 928-944. DOI: http://dx.doi.org/10.1016/j.conbuildmat.2017.08.005.

[31] Lynn, C. J., Dhir, R. K., and Ghataora, G. S. 2016. Municipal Incinerated Bottom Ash Characteristics and Potential for Use as Aggregate in Concrete. Construction and Building Materials. 127: 504-517.

DOI: http://dx.doi.org/10.1016/j.conbuildmat.2016.09.132.

[32] Černý, V., and Tưmová, E. 2016. Effect of Firing Temperature on the Structure of the Aggregate from Sintered Ashes. Procedia Engineering. 151: 345-351. DOI: http://dx.doi.org/10.1016/j.proeng.2016.07.378.

[33] Azrar, H., Zentar, R., and Abriak N. E. 2016. The Effect of Granulation Time of the Pan Granulation on the Characteristics of the Aggregates Containing Dunkirk Sediments. Procedia Engineering. 143: 10-17. DOI: http://dx.doi.org/10.1016/j.proeng.2016.06.002.

[34] Yuan, J., Dong, W., Chen, J., Zhang, S., Qian, W., and Sun, W. 2015. A LED-Based Measurement System for Affinity Between Bitumen and Aggregate. Construction and Building Materials. 81: 298-302. DOI: $\mathrm{http}: / /$ dx.doi.org/10.1016/j.conbuildmat.2014.12.066.

[35] Gomathi, P., and Sivakumar, A. 2015. Accelerated Curing Effects on the Mechanical Performance of Cold Bonded and Sintered Fly Ash Aggregate Concrete. Construction and Building Materials. 77: 276-287.

DOI: http://dx.doi.org/10.1016/j.conbuildmat.2014.12.108.

[36] Han, M. C., Han, D., and Shin, J. K. 2015. Use of Bottom Ash and Stone Dust to Make Lightweight Aggregate. Construction and Building Materials. 99: 192-199. DOI: http://dx.doi.org/10.1016/j.conbuildmat.2015.09.036.

[37] Guneyisi, E., Gesoglu, M., Altan, I., and Oz, H. O. 2015. Utilization of Cold Bonded Fly Ash Lightweight Fine Aggregates as a Partial Substitution of Natural Fine Aggregate in Self-Compacting Mortars. Construction and Building Materials. 74: 9-16. DOI: http://dx.doi.org/10.1016/j.conbuildmat.2014.10.021.

[38] Mizuriaev, S. A., Montaev, S. A., and Taskaliev, A. T. 2015. Artificial Broken Stone Production for Industrial and Civil
Engineering: Technological Parameters. Procedia Engineering. 111: 534-539.

DOl: http://dx.doi.org/10.1016/j.proeng.2015/07.037.

[39] Wang, W., Chen, J., Sun, Y., XU, B., Li, J., and Liu, J. 2017. Laboratory Performance Analysis of High Percentage Artificial RAP Binder with WMA Additives. Construction and Building Materials. 147: 58-65. DOI: http://dx.doi.org/10.1016/j.conbuildmat.2017.04.142.

[40] Liu, P. 2017. Modelling and Evaluation of Aggregate Morphology on Asphalt Compression Behavior. Construction and Building Materials. 133: 196-208. DOI: http://dx.doi.org/10.1016/j.conbuildmat.2016.12.041.

[41] Ahyudanari, E., Ekaputri, J. J., and Tardas, M. 2016. Analysis of Coal Waste Solidification as an Alternative Filler Material in Asphalt Concrete Mixture. Materials Science Forum. 841: 65-71.

DOI: 10.4028/www.scientific.net/MSF.841.65.

[42] Mistry, R., and Roy, T. K. 2016. Effect of Using Fly Ash as Alternative Filler in Hot Mix Asphalt. Perspectives on Science. 8: 307-309.

DOI: http://dx.doi.org/10.1016/j.pisc.2016.04.061.

[43] Widayanti, A., Soemitro, R. A. A., Ekaputri, J. J., and Suprayitno, H. 2018. Characterization and Compressive Strength of Fly Ash Based-Geopolymer Paste. MATEC Web of Conferences. 195 (2018): 1023-1033. DOI: https://doi.org/10.1051/matecconf/201819501023.

[44] Ibrahim, A. N. H., Yusoff, N. I. M., Akhir, N. M., and Borhan, M. N. 2016. Physical Properties and Storage Stability of Geopolymer Modified Asphalt Binder. Jurnal Teknologi. 78(7-2): 133-138. DOI: http://dx.doi.org/10.11113/jt.v78.9508.

[45] Indonesian Standard. 2018. General Specifications of Bina Marga. Directorate General of Bina Marga. The Ministry of Public Works. 6-1.

[46] Islam, A., Alengaram, U. J., Jumaat, M. Z., Ghazali, N. B., and Yusoff, S. 2017. Influence of Steel Fibers on the Mechanical Properties and Impact Resistance of Lightweight Geopolymer Concrete. Construction and Building Materials. 152: 964-977.

DOI: http://dx.doi.org/10.1016/j.conbuildmat.2017.06.092.

[47] Nicholls, J. C., Visscher, J., Hammoum, F., and Jacobs, M. 2015. DRaT - Development of the Ravelling Test Review of Parameters Influencing the Propensity of Asphalt to Ravel. CEDR Conference of European Directors of Roads. 1-32. DOI: http://dx.doi.org/10.1007/978-94-017-7342-3_63.

[48] D'Angelo, G., Ojum, C., Widyatmoko, I., Wayman, M., and Khojinian, A. 2020. Ravelling Resistance of UK Thin Asphalt Surface Course Systems Under A Large-Scale Accelerated Test Method. International Journal of Pavement Engineering \& Asphalt Technology. 1-14.

DOl: http://dx.doi.org/10.1515/ijpeat-2016-0035.

[49] Xie, J., Wu, S., Pang, L., Lin, J., and Zhu, Z. 2012. Influence of Surface Treated Fly Ash with Coupling Agent on Asphalt Mixture Moisture Damage. Construction and Building Materials. 30: 340-346. DOI: http://dx.doi.org/10.1016/j.conbuildmat.2011.11.022.

[50] Güneyisi, E., Gesoglu, M., Ghanim, H., Ipek, S., and Taha, I. 2016. Influence of the Artificial Lightweight Aggregate on Fresh Properties and Compressive Strength of The SelfCompacting Mortars. Construction and Building Materials. 116: 151-158. DOI: http://dx.doi.org/10.1016/j.conbuildmat.2016.04.140.

[51] Sarmin, S. N., and Welling, J. 2016. Lighweight Geopolymer Wood Composite Synthesized from Alkali-Activated Fly Ash and Metakaolin. Jurnal Teknologi. 78(11): 49-55. DOI: http://dx.doi.org/10.11113/jt.v78.8734.

[52] Güneyisi, E., Gesoglu, M., Azez, O. A., and Oz, H. O. 2016. Effect of Nano Silica on the Workability of SelfCompacting Concretes Having Untreated and Surface Treated Lightweight Aggregates. Construction and Building Materials. 115: 371-380.

DOI: http://dx.doi.org/10.1016/j.conbuildmat.2016.04.055.

[53] Pasetto, M., and Baldo, N. 2016. Recycling of Waste 
Aggregate in Cement Bound Mixtures for Road Pavement Bases and Sub-Bases. Construction and Building Materials. 108: $112-118$.

DOI: http://dx.doi.org/10.1016/j.conbuildmat.2016.01.023.

[54] Akacem, M., Bouteldja, M., Cerezo, V., and Hachichi, A. 2016. A Method to Use Local Low Performances Aggregates in Asphalt Pavements - An Algerian Case Study. Construction and Building Materials. 125: 290-298. DOI: http://dx.doi.org/10.1016/j.conbuildmat.2016.08.035.

[55] Sanjayan, J. G., Nazari, A., Chen, L., and Nguyen, G. H. 2015. Physical and Mechanical Properties of Lightweight Aerated Geopolymer. Construction and Building Materials. 79: 236-244.

DOI: http://dx.doi.org/10.1016/j.conbuildmat.2015.01.043.

[56] Chen, C., Ji, T., Zhuang, Y., and Lin, X. 2015. Workability, Mechanical Properties and Affinity of Artificial Reef Concrete. Construction and Building Materials. 98: 227-236. DOI: http://dx.doi.org/10.1016/j.conbuildmat.2015.05.109.
[57] Yoon, M., Kim, G., Choe, G. C., Lee, Y., and Lee, T. 2015. Effect of Coarse Aggregate Type and Loading Level on The High Temperature Properties of Concrete. Construction and Building Materials. 78: 26-33. DOI: http://dx.doi.org/10.1016/j.conbuildmat.2014.12.096.

[58] Guneyisi, E., Gesoglu, M., Azez, O. A., and Oz, H. O. 2015. Physico-Mechanical Properties of Self-Compacting Concrete Containing Treated Cold-Bonded Fly Ash Lightweight Aggregates and $\mathrm{SiO}_{2}$ Nano-Particles. Construction and Building Materials. 101: 1142-1153. DOI: http://dx.doi.org/10.1016/j.conbuildmat.2015.10.117.

[59] Yan, C., Huang, W., and LV, Q. 2016. Study on Bond Properties Between RAP Aggregates and Virgin Asphalt Using Binder Bond Strength Test and Fourier Transform Infrared Spectroscopy. Construction and Building Materials. 124: 1-10.

DOl: http://dx.doi.org/10.1016/j.conbuildmat.2016.07.024. 